\title{
Synthesis and Antimalarial Activity Evaluation of Some Mannich Bases of Tetraoxane-Phenol Conjugate
}

\author{
Gogoi Jinky, Chetia Dipak, Kumawat Kumar Mukesh, Rudrapal Mithun
}

Department of Pharmaceutical Sciences, Dibrugarh University, Dibrugarh, Assam, INDIA.

\begin{abstract}
A new series of seven Mannich bases of tetraoxane-phenol conjugate as possible antimalarial compounds were synthesized and evaluated in vitro for their antimalarial activity. All the synthesized compounds exhibited good antimalarial activity against the CQ-sensitive strain (RKL-2) of $P$. falciparum. Compounds with 3 -indolyl and phenolic substituent's showed considerably superior activity than rest of the synthesized tetraoxane derivatives in the series, with $\mathrm{IC}_{50}$ values $8.19 \mu \mathrm{g} / \mathrm{ml}$ and $5.30 \mu \mathrm{g} / \mathrm{ml}$, respectively. The activity was, however, less than that of the standard reference drug, CQ $\left(\mathrm{IC}_{50} 0.04\right.$ $\mu \mathrm{g} / \mathrm{ml}$ ). Three selected compounds were also screened for the activity against a CQresistant strain (RKL-9) of $P$. falciparum, which was also found good with $\mathrm{IC}_{50}$ values $41.77 \mu \mathrm{g} / \mathrm{ml}, 39.87 \mu \mathrm{g} / \mathrm{ml}$ and $34.59 \mu \mathrm{g} / \mathrm{ml}$ for compounds having phenyl, furan-2-yl and 4-pyridyl substituent's, respectively in the Mannich base component of the conjugated tetraoxane-phenol scaffold. The activity against CQ-sensitive strain of $P$. falciparum was better as compared to the activity seen against resistant strain. Results clearly indicate that Mannich bases of tetraoxane-phenol conjugate with bulky aromatic/heteroaromatic groups possess antimalarial potential both against CQ-sensitive and -resistant strains of P. falciparum.
\end{abstract}

Key words: Mannich base, Tetraoxane, Endoperoxide, Plasmodium falciparum, Resistant malaria.

\section{INTRODUCTION}

Malaria continues to be one of the most lethal parasitic diseases worldwide, which affects approximately 207 million people resulting in 6, 27,000 deaths per year globally, particularly in the tropical and sub-tropical regions of the world. ${ }^{1}$ The disease is caused by four protozoan parasite species of the genus Plasmodium; namely, P. vivax, P. malariae, P. ovale and P. falciparum. P. falciparum being the most pernicious species is attributed to be the cause of a majority of malaria related morbidity and mortality in the malaria endemic regions of the world. ${ }^{2,3}$ Since last two decades, the clinical usefulness of chloroquine (CQ) and other related quinolinebased antimalarial drugs has been seriously compromised because of the emergence of resistance of malaria parasites, especially, P. falciparum. ${ }^{4,5}$ The rapid spread of resistance of P. falciparum towards currently available drugs including artemisinin (ART) and its semi-synthetic endoperoxide has therefore become a major concern of public health in the developing world. ${ }^{6}$ The above issue could be addressed with the discovery and development of novel antimalarial agents that would effectively fight against resistant malaria strain.

Structure-activity relationship studies on ART and its semi-synthetic derivatives such as artemether and artesaunate revealed that the peroxide linkage (i.e., endoperoxide
Submission Date : 12-05-2016 Revision Date : :31-08-2016 Accepted Date : 19-09-2016

DOI: 10.5530/ijper.50.4.11 Correspondence: Mithun Rudrapal, Department of Pharmaceutical Sciences, Dibrugarh University,Dibrugarh-786004, Assam, INDIA.

Phone no: +91-9642785523

E-mail: rudrapal.m03@ gmail.com

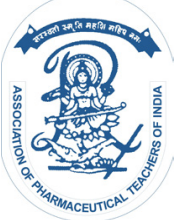

www.ijper.org 
group) is an integral structural part (called as pharmacophore) for their antimalarial activity. The endoperoxide group after cleavage in presence of heme $\left(\mathrm{Fe}_{2}\right)$ in the parasite generate cytotoxic free radicals which eventually render parasite to die (Figure 1). ${ }^{7}$ ART based drugs which are available in the market are considerably more expensive, not readily available and having poor pharmacokinetic properties. ${ }^{8}$ Tetraoxanes are known to be a newer class of synthetic endoperoxide that are based on the structural framework of ART. It is attributed that tetraoxanes have similar mode of action to that of naturally occurring ART and other endoperoxide. ${ }^{9,10}$ Therefore, the design of newer tetraoxane-based endoperoxide could be an attractive strategy in the development of novel antimalarial agents with improved bioactivity features, particularly in terms of targeting the malaria parasite with resistant preventing property.

In this paper, some newer Mannich base derivatives of the tetraoxane endoperoxide scaffold have been proposed to be synthesized for the evaluation of their antimalarial activity. The rationale behind the incorporation of Mannich structural substitution in the tetraoxanephenol conjugate is to preclude the known toxicological effects already associated with available quinoline-based drugs, while retaining the ability to inhibit heme detoxification mechanism (hemozoin formation). ${ }^{11}$ Furthermore, Mannich base phenol conjugated with the core pharmacophoric tetraoxane ring system may offer a novel structural motif for the development of newer antimalarial agents for the treatment of resistant malaria.

\section{MATERIALS AND METHODS \\ Chemicals and Analysis}

All chemicals used in the study were procured either from Sisco Research Laboratories or from Spectrochem Pvt. Ltd., India, and were used without further purification. The melting points of the synthesized compounds were determined by using Veego-MPI melting point apparatus. The progress of reactions was monitored on silica gel-G TLC plate using various solvent combinations. The spots were detected with iodine vapours followed by observing under UV-light (at $254 \mathrm{~nm}$ ). The UVvisible spectra of the synthesized compounds were recorded on a UV-visible spectrophotometer (Shimadzu UV-1800). Infrared spectra were recorded on an FT-IR Perkin-Elmer spectrometer. The ${ }^{1} \mathrm{H}$ and ${ }^{13} \mathrm{C}$ NMR spectra were recorded at $400 \mathrm{MHz}$ and $100 \mathrm{MHz}$, respectively, on a Bruker Avance-II 400 NMR spectrometer using DMSO- $d 6$ as a solvent with tetramethylsilane (TMS) as an internal standard.

\section{General Procedure of Synthesis ${ }^{11-14}$}

Step-1: Synthesis of phenyl gem-dihydroperoxide (2): 4-Hydroxyacetophenone $(1 \mathrm{ml}, 10 \mathrm{mmol})$ was dissolved in a mixture of $\mathrm{CH}_{2} \mathrm{Cl}_{2} / \mathrm{CH}_{3} \mathrm{CN}(20 \mathrm{ml}, 1: 3 \mathrm{v} / \mathrm{v})$ followed by the addition of $30 \% \mathrm{H}_{2} \mathrm{O}_{2}(10.4 \mathrm{ml}, 0.1 \mathrm{~mol})$ and $3 \mathrm{ml}$ of conc. $\mathrm{HCl}$. The reaction mixture was stirred at room temperature for $2 \mathrm{~h}$, and then quenched with saturated solution of aqueous $\mathrm{NaHCO}_{3}$ and $\mathrm{CH}_{2} \mathrm{Cl}_{2}$. The organic layer was separated out, and the aqueous layer was filtered and dried.

Step-2: Synthesis of phenyl tetraoxanes (4): The desired heteroaryl aldehyde $(0.36 \mathrm{~g}, 2.3 \mathrm{mmol})$ was added to an ice-cooled solution of phenyl gem-dihydroperoxide $(0.34 \mathrm{~g}, 2.3 \mathrm{mmol})$ in $\mathrm{CH}_{2} \mathrm{Cl}_{2}(20 \mathrm{ml})$. The mixture was stirred at room temperature for $30 \mathrm{~min}$, followed by the drop wise addition of an ice-cooled mixture of $\mathrm{H}_{2} \mathrm{SO}_{4} /$ $\mathrm{CH}_{3} \mathrm{CN}(1.66 \mathrm{ml}, 1: 10, \mathrm{v} / \mathrm{v})$. After an additional $50 \mathrm{~min}$ of stirring, the reaction mixture was dried at room temperature.

Step-3: Synthesis of target Mannich base tetraoxane derivatives (5a-g): The phenol tetraoxane $(0.05 \mathrm{~mol})$ was subjected to Mannich reaction with a secondary amine $(0.1 \mathrm{~mol})$ and aqueous formaldehyde $(0.1 \mathrm{~mol})$ in the presence of ethanol as solvent. After $16 \mathrm{~h}$ of refluxing at $78-80^{\circ} \mathrm{C}$ the solvent was removed under reduced pressure and the residue was dissolved in approximately $50 \mathrm{ml}$ of $\mathrm{CH}_{2} \mathrm{Cl}_{2}$. The organic solution was extracted with dil. hydrochloric acid $(0.1 \mathrm{M}, 2 \times 75 \mathrm{ml})$ and then the solution was basified ( $\mathrm{pH} 9-10)$ and again extracted with dichloromethane $(3 \times 75 \mathrm{ml})$. The combined organic extract was washed with water $(1 \times 100 \mathrm{ml})$ and dried using anhydrous sodium sulphate and then solvent was evaporated under reduced pressure to yield the final product. The crude compound was recrystallized with from ethanol.

\section{Antimalarial Activity Evaluation}

All the synthesized compounds were screened for in vitro antimalarial activity against a CQ-sensitive strain (RKL-2, Rourkela, Odisha, India) of P. falciparum (Pf). Additionally, three selected compounds were also screened for the activity against a CQ-resistant strain (RKL-9, Rourkela, Odisha, India) of $P$. falciparum. The antimalarial activity screening was carried out by Giemsa stained slide.

The laboratory adapted strain of Pf was routinely cultured in vitro at $37^{\circ} \mathrm{C}$ temperature and $5 \% \mathrm{CO}_{2}$ environment in RPMI-1640 medium supplemented with $25 \mathrm{mM}$ HEPES, 1\% D-glucose, $0.23 \%$ sodium bicarbonate, gentamycin $(40 \mathrm{mg} / \mathrm{ml})$, amphotericin-B $(0.25 \mathrm{mg} / \mathrm{ml})$ and $10 \%$ heat inactivated human serum. For antimalarial testing, the asynchronous parasites of Pf were synchronized by $5 \% \mathrm{D}$-sorbitol treatment to obtain only the ring stage parasitized cells. For carrying 
out the assay, the initial ring stage parasitaemia of $0.8-1.5 \%$ in 3\% haematocrit in a total volume of $100 \mathrm{ml}$ using RPMI-1640 medium was uniformly maintained. A stock solution $(1 \mathrm{mg} / \mathrm{ml})$ of the test compound was prepared in DMSO and subsequent dilutions were made with the incomplete RPMI culture medium. $100 \mu \mathrm{l}$ of the test compound at $0.1 \mathrm{mg} / \mathrm{ml}$ concentration (in triplicate) was incubated with parasitized cell preparation at $37^{\circ} \mathrm{C}$ and $5 \% \mathrm{CO}_{2}$ in a $\mathrm{CO}_{2}$ incubator. After an incubation period of 36-40 h, blood smears were prepared from each well and stained with 3\% Giemsa stain. The slides were observed under the light microscope and the percentage dead rings +trophozoites were calculated against 200 asexual parasites with respect to the control group. Chloroquine $(0.1 \mathrm{mg} / \mathrm{ml})$ was used as the standard reference drug. ${ }^{15,16}$ Test results were compared with the standard result of CQ. Each test compound was assayed in three replicates and counted against 200 asexual parasites (\% dead rings+trophozoites) per replicate. The percentage of inhibition of parasite growth (antimalarial activity) was obtained as mean of triplicate studies. The minimum inhibitory concentration (MIC) and $\mathrm{IC}_{50}$ values (in $\mu \mathrm{g} / \mathrm{ml}$ ) were calculated using the NonLin V1.1 software.

\section{RESULTS AND DISCUSSION}

\section{Chemistry}

The synthesis of target tetraoxane derivatives involved a three-step simple organic reaction (Figure 2) in which the phenyl carbonyl compound (4-hydroxyacetophenone) was initially converted into a phenyl gem-dihydroperoxide, which at the later stage of reaction reacted with the required aromatic aldehyde to obtain the corresponding phenol-tetraoxane derivatives. Finally, phenol-tetraoxane conjugates upon Mannich condensation yielded target molecules in which conjugated phenol-tetraoxane system is appended with structurally diverse aromatic and/or heteroaromatic Mannich base substituents. The physicochemical details of the synthesized compounds, $\mathbf{5 a - g}$ is presented in Table 1 . The spectral data (FT-IR, ${ }^{1} \mathrm{H}$ NMR \& ${ }^{13} \mathrm{C}$ NMR) are depicted as follows:

2-((Etbyl(phenyl)amino)methyl)-4-(3-methyl-6-phenyl-1,2,4,5tetraoxan-3-yl)phenol (5a): UV ( $\lambda_{\max }$, in $\left.\mathrm{nm}, \mathrm{CH}_{2} \mathrm{Cl}_{2}\right)$ : 303.80; FT-IR ( $\nu_{\max }$ in $\mathrm{cm}^{-1}$, Film): 3394.51 (-OH str.), 2968, 2869.45 (C-H str., methyl group), 1512.50 (C=C str., Ar. ring), 1255.99 (C-O str.), 1104.81 (C-N str.); ${ }^{1} \mathrm{H}$ NMR (400 MHz, $\delta$ in ppm, DMSO-d6): 1.83 (s, 3H, $\left.\mathrm{CH}_{3}\right), 4.22\left(\mathrm{~s}, 2 \mathrm{H},-\mathrm{CH}_{2}^{-}\right), 5.21$ (s, 1H, OH), 6.41 (s, 1H, - $\mathrm{CH}$-, tetraoxane), 7.41 (m, 5H, phenyl ring), 7.65 (m, $5 \mathrm{H}$, phenyl ring), 7.84 ( $\mathrm{m}, 5 \mathrm{H}$, phenyl ring); ${ }^{13} \mathrm{C} \mathrm{NMR}$
(100 MHz, $\delta$ in ppm, DMSO-d6): 15.33, 21.45, 42.95, 51.13, 63.58, 79.38, 117.52, 118.89,119.27, 123.29, 128.98, 130.56, 132.38, 156.28.

2-((Ethyl(phenyl)amino)methyl)-4-(6-(furan-2-yl)-3-metbyl1,2,4,5-tetraoxan-3-yl)phenol (5b): UV $\left(\lambda_{\max }\right.$, in $\mathrm{nm}$, $\left.\mathrm{CH}_{2} \mathrm{Cl}_{2}\right): 306.40$; FT-IR $\left(\nu_{\max }\right.$, in $\mathrm{cm}^{-1}$, Film): 3393.98 (-OH str.), 2870.62, 2925.00 (C-H str., methyl group), 1512.04 (C=C str., Ar. ring), 1252.40 (C-O str.), 1145.13 (R-O-R, cyclic ether), 1101.08 (C-N str.); ${ }^{1} \mathrm{H}$ NMR (400 $\mathrm{MHz}, \delta$ in ppm, DMSO-do): 1.07 (s, $\left.3 \mathrm{H},-\mathrm{CH}_{3}\right), 1.82$ $\left(\mathrm{s}, 3 \mathrm{H},-\mathrm{CH}_{3}\right), 4.52\left(\mathrm{~s}, 2 \mathrm{H},-\mathrm{CH}_{2}-\right), 5.40(\mathrm{~s}, 1 \mathrm{H},-\mathrm{OH})$, 7.40-7.83 (m, 5H, phenyl ring); ${ }^{13} \mathrm{C}$ NMR (100 MHz, $\delta$ in ppm, DMSO-do): 14.92, 21.02, 42.70, 50.84, 63.23, $78.84,117.45,118.51,122.81,123.98,126.14,128.63$, 129.56, 130.21,131.62,155.88.

2-((Ethyl(phenyl)amino)methyl)-4-(3-methyl-6-(thiophen-2-yl)1,2,4,5-tetraoxan-3-yl)phenol (5c): UV $\left(\lambda_{\max }\right.$, in $\mathrm{nm}$, $\left.\mathrm{CH}_{2} \mathrm{Cl}_{2}\right): 302.40$; FT-IR $\left(\nu_{\max }\right.$, in $\mathrm{cm}^{-1}$, Film): 3393.03 (-OH str.), 2871.37, 2968.09 (C-H str., methyl group), 1512.40 (C=C str., Ar. ring), 1254.05 (C-O str.), 802.13 (C-S str.); ${ }^{1} \mathrm{H}$ NMR (400 MHz, $\delta$ in ppm, DMSO-dఠ): $1.72\left(\mathrm{~s}, 3 \mathrm{H},-\mathrm{CH}_{3}\right), 2.33\left(\mathrm{~s}, 3 \mathrm{H},-\mathrm{CH}_{3}\right), 5.45(\mathrm{~s}, 1 \mathrm{H},-\mathrm{OH})$, 7.91-8.00 (m, 5H, phenyl ring); ${ }^{13} \mathrm{C}$ NMR (100 MHz, $\delta$ in ppm, DMSO-d6): $\delta 38.69,39.31,39.73,39.94,52.68$, 66.13, 78.40, 78.61 .

2-((Ethyl(phenyl)amino)methyl)-4-(3-methyl-6-(pyridin-2-yl)1,2,4,5-tetraoxan-3-yl)phenol (5d): UV $\lambda_{\max }$, in $\mathrm{nm}$, $\left.\mathrm{CH}_{2} \mathrm{Cl}_{2}\right): 263.40$; FT-IR ( $\nu_{\max }$, in $\mathrm{cm}^{-1}$, Film) 3524.56 (-OH str.), 2868.84, 2970.72 (C-H str., methyl group), 1513.40,1577.53 ( $\mathrm{C}=\mathrm{C}$, Ar. ring), 1266.15 (C-O str.), 1102.93 (C-N str.); ${ }^{1} \mathrm{H}$ NMR (400 MHz, $\delta$ in ppm, DMSO-d6): $\delta 1.66$ (s, $\left.3 \mathrm{H},-\mathrm{CH}_{3}\right), 1.83\left(\mathrm{~s}, 3 \mathrm{H},-\mathrm{CH}_{3}\right)$, 3.18 (s, 2H, $\left.-\mathrm{CH}_{2}-\right), 5.87(\mathrm{~s}, 1 \mathrm{H},-\mathrm{OH}), 6.57(\mathrm{~s}, 1 \mathrm{H},-\mathrm{CH}-$, Tetraoxane), $\left.6.64\left(\mathrm{~m}, 5 \mathrm{H}, \mathrm{C}_{6} \mathrm{H}_{5}-\right), 7.40\left(\mathrm{~m}, 5 \mathrm{H}, \mathrm{C}_{6} \mathrm{H}_{5}\right)^{-}\right)$, 7.50-8.91 (s, 1H, -CH-, 4-pyridyl); ${ }^{13} \mathrm{C}$ NMR $(100 \mathrm{MHz}$, $\delta$ in ppm, DMSO-do): $\delta 18.57,20.35,39.91,40.12$, 79.41, 125.18.

2-((Ethyl(phenyl)amino)methyl)-4-(3-metbyl-6-(pyridin-4-yl)1,2,4,5-tetraoxan-3-yl)phenol (5e): UV $\left(\lambda_{\max }\right.$, in $\mathrm{nm}$, $\left.\mathrm{CH}_{2} \mathrm{Cl}_{2}\right): 266.40 \mathrm{~nm}$; FT-IR $\left(\nu_{\text {max }}\right.$, in $\mathrm{cm}^{-1}$, Film) 3383.38 (-OH str.), 2791.19, 2969.00 (C-H str., methyl group), 1512.86, 1595.42 ( $\mathrm{C}=\mathrm{C}, \mathrm{C}=\mathrm{N}$ str., Ar. ring), 1262.95 (C-O str.), 1100.65 (C-N str.); ${ }^{1} \mathrm{H}$ NMR (400 MHz, $\delta$ in ppm, DMSO-do): $\delta 1.14\left(\mathrm{~s}, 3 \mathrm{H},-\mathrm{CH}_{3}\right), 1.34(\mathrm{~s}, 3 \mathrm{H}$, $\left.-\mathrm{CH}_{3}\right), 5.74$ (s, $\left.1 \mathrm{H},-\mathrm{OH}\right), 6.20(\mathrm{~s}, 1 \mathrm{H}$, tetraoxane), 6.56 (s, 1H, -CH-, Ar), 6.61 (s, 1H, -CH-, Ar), 7.08 (m, 5H, $\left.\mathrm{C}_{6} \mathrm{H}_{5}-\right), 7.53\left(\mathrm{~m}, 4 \mathrm{H},-\mathrm{C}_{5} \mathrm{H}_{4} \mathrm{~N}\right) ;{ }^{13} \mathrm{C}$ NMR $(100 \mathrm{MHz}, \delta$ in ppm, DMSO-d6): $\delta 13.52,19.20,40.14,46.55,116.71$, 121.62, 123.69, 135.90, 149.41.

4-(6-(1H-Indol-2-yl)-3-methyl-1,2,4,5-tetraoxan-3-yl)-2 ((etbyl (phenyl) amino) metbyl) phenol (5f): UV ( $\lambda_{\max }$, in $\mathrm{nm}$, $\left.\mathrm{CH}_{2} \mathrm{Cl}_{2}\right): 296.80$; FT-IR $\left(\nu_{\max }\right.$, in $\mathrm{cm}^{-1}$, Film) 3393.49 


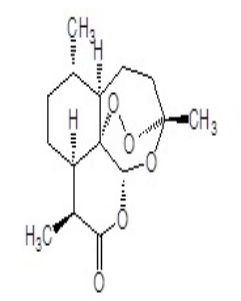

ART

(Endoperoxide)

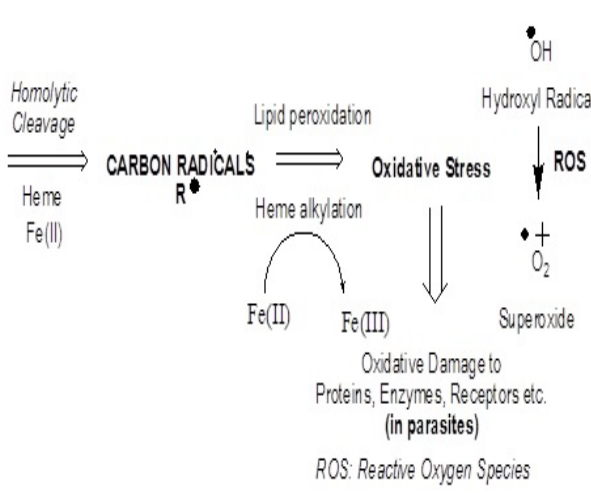

Figure 1: Antimalarial action of endoperoxides against $P$. falciparum.

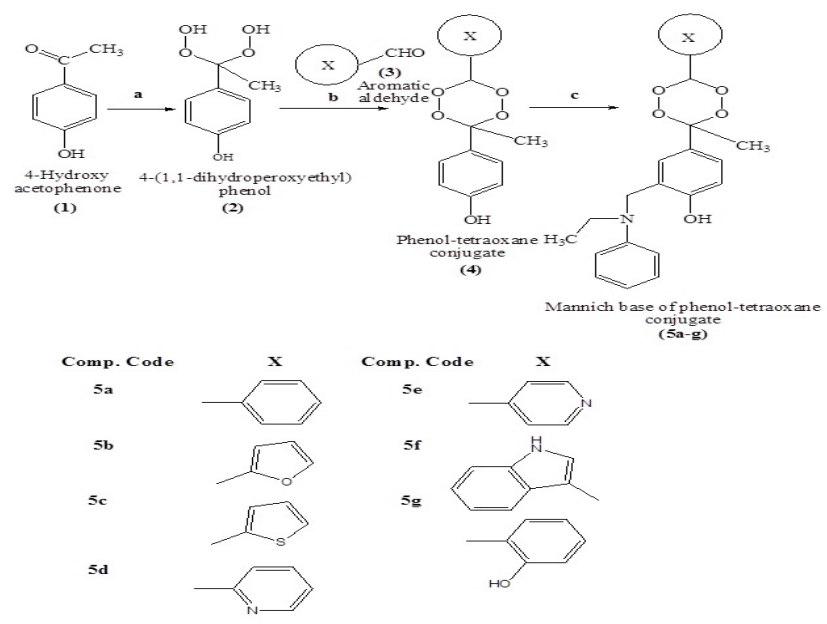

Figure 2: Synthesis of targeted compounds, 5a-g; Reagents and reaction condition: a (Step 1), $\mathrm{CH}_{3} \mathrm{CN}, \mathrm{CH}_{2} \mathrm{Cl}_{2}$, Conc. $\mathrm{HCl}$,

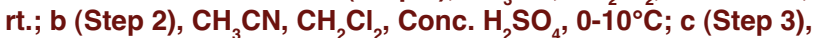
$\mathrm{C}_{6} \mathrm{H}_{5} \mathrm{NHC}_{2} \mathrm{H}_{5}$ (1 eqv.), $\mathrm{HCHO}$ (1 eqv.), ethanol, reflux for $16 \mathrm{~h}$.

\section{Table 1: Physicochemical Details of Synthesized Compounds*, 5a-g}

\begin{tabular}{|c|c|c|c|c|c|}
\hline $\begin{array}{c}\text { Comp. } \\
\text { code }\end{array}$ & State & Colour & $\%$ Yield & $\mathbf{R}_{\mathbf{f}}{ }^{*}$ & $\begin{array}{c}\text { Melting point } \\
\left({ }^{\circ} \mathbf{C}\right)\end{array}$ \\
\hline $\mathbf{5 a}$ & Semisolid & Red & 78 & 0.71 & - \\
\hline $\mathbf{5 b}$ & Solid & Orange & 73 & 0.64 & $110-114$ \\
\hline $\mathbf{5 c}$ & Semisolid & Purple & 74 & 0.65 & - \\
\hline $\mathbf{5 d}$ & Semisolid & Maroon & 80 & 0.61 & - \\
\hline $\mathbf{5 e}$ & Semisolid & Red & 71 & 0.67 & - \\
\hline $\mathbf{5 f}$ & Solid & Orange & 75 & 0.73 & $91-94^{\circ} \mathrm{C}$ \\
\hline $\mathbf{5 g}$ & Solid & Red & 79 & 0.88 & $77-82^{\circ} \mathrm{C}$ \\
\hline
\end{tabular}

*Solubility: Soluble in dichloromethane and DMSO

"Solvent: Pet. ether: acetone $=2: 8$

\begin{tabular}{|c|c|c|}
\hline \multicolumn{2}{|c|}{ Table 2: Results of In Vitro Antimalarial Activity\# } \\
\hline Comp. code $^{\boldsymbol{s}}$ & MIC $(\boldsymbol{\mu g} / \mathbf{m L})^{*}$ & IC $_{50}(\boldsymbol{\mu g} / \mathbf{m L})^{*}$ \\
\hline $\mathbf{5 a}$ & $25(125)^{* *}$ & $10.08(39.87)^{* *}$ \\
\hline $\mathbf{5 b}$ & $31.25(125)^{* *}$ & $16.36(41.77)^{* *}$ \\
\hline $\mathbf{5 c}$ & 25 & 12.73 \\
\hline $\mathbf{5 d}$ & 31.25 & 14.40 \\
\hline $\mathbf{5 e}$ & $31.25(62.5)^{* *}$ & $18.60(34.59)^{* *}$ \\
\hline $\mathbf{5 f}$ & 12.50 & 8.19 \\
\hline $\mathbf{5 g}$ & 6.25 & 5.30 \\
\hline $\mathbf{C Q}$ & 0.4 & 0.04 \\
\hline
\end{tabular}

"Data are presented as mean of triplicate observations

${ }^{*}$ CQ-sensitive P. falciparum (RKL-2) strain

${ }^{* *} C Q$-resistant $P$. falciparum ( $\left.R K L-9\right)$ strain

${ }^{s}$ Test dose: $100 \mu \mathrm{g} / \mathrm{mL}$ 
(-OH str.), 2922.57, 2968.34 (C-H str., alkyl group), 1513.71 ( $\mathrm{C}=\mathrm{C}$ str., Ar. ring), $1346.88(\mathrm{C}=\mathrm{N}$ str., Ar. ring), 1265.82 (C-O str.), 1105.53 (C-N str.); ${ }^{1} \mathrm{H}$ NMR (400 MHz, $\delta$ in ppm, DMSO-do): $\delta 1.48\left(\mathrm{~s}, 3 \mathrm{H},-\mathrm{CH}_{3}\right)$, $1.98\left(\mathrm{~s}, 3 \mathrm{H},-\mathrm{CH}_{3}\right), 3.58\left(\mathrm{~s}, 2 \mathrm{H},-\mathrm{CH}_{2}-\mathrm{N}\right), 3.95$ (s, $2 \mathrm{H}$, $\left.-\mathrm{CH}_{2}-\right), 5.44$ (s, 1H, -OH), 7.33 (m, 4H, 3-indolyl), 9.87 (s, $1 \mathrm{H},-\mathrm{NH}-, 3$-indolyl); ${ }^{13} \mathrm{C}$ NMR $(100 \mathrm{MHz}, \delta$ in ppm, DMSO-do): $\delta 11.59,18.85,40.53,46.85,114.98,115.28$, $118.64,119.69,120.82,121.22,122.06,123.73,130.87$, 135.94, 149.44, 152.97.

2-(6-(3-((ethyl(phenyl)amino)methyl)-4-hydroxyphenyl)-6methyl-1,2,4,5-tetraoxan-3-yl)phenol (5g): UV $\left(\lambda_{\max }\right.$, in $\mathrm{nm}$, $\left.\mathrm{CH}_{2} \mathrm{Cl}_{2}\right): 258.20$; FT-IR $\left(\nu_{\max }\right.$, in $\mathrm{cm}^{-1}$, Film) 3394.95 (-OH str.), 1511.17 (C=C str., Ar. ring), 1266.35 (C-O str.), 1104.81 (C-N str.); ${ }^{1} \mathrm{H}$ NMR $(400 \mathrm{MHz}, \delta$ in ppm, DMSO-d6): $\delta 1.37$ (s, 3H, $\left.-\mathrm{CH}_{3}\right), 1.74\left(\mathrm{~s}, 3 \mathrm{H},-\mathrm{CH}_{3}\right)$, 3.55 (s, 2H, - $\left.\mathrm{CH}_{2}-\mathrm{N}\right), 5.66(\mathrm{~s}, 1 \mathrm{H},-\mathrm{OH}), 7.36(\mathrm{~m}, 4 \mathrm{H}$, $\left.\mathrm{C}_{6} \mathrm{H}_{4}-\right), 7.38\left(\mathrm{~m}, 5 \mathrm{H}, \mathrm{C}_{6} \mathrm{H}_{5}-\right) ;{ }^{13} \mathrm{C}$ NMR $(100 \mathrm{MHz}, \delta$ in ppm, DMSO-d6): $\delta 12.02,18.24,39.36,42.20,115.32$, $118.27,119.20,120.22,121.80,122.01,123.67,130.48$, $135.24,150.10,152.26$.

UV spectral data $\left(\lambda_{\max }\right.$ in dichloromethane) indicate the presence of phenol conjugate of tetraoxane ring system with Mannich substitution as the fundamental structural moiety of the synthesized compounds (5a-g). Results of FT-IR spectral analysis exhibited characteristic absorption peaks due to functional peroxide group (C-O-O), phenolic $-\mathrm{OH}$ group, methyl group and aromatic $\mathrm{C}-\mathrm{H}, \mathrm{C}-\mathrm{O}, \mathrm{C}-\mathrm{S}, \mathrm{C}-\mathrm{N}$ bonds present in the synthesized compounds. ${ }^{1} \mathrm{H}$ NMR spectral data as described above exhibited prominent singlet for hydroxyl and methyl protons and also characteristic peak multiplicity pattern for phenyl, 2-pyridyl and 3-indolyl ring systems found as Mannich substituents in the structure of compounds. ${ }^{13} \mathrm{C}$ NMR data further confirms the skeletal structure (penolic-tetraoxane scaffold) of the synthesized compounds. ${ }^{17}$

\section{Antimalarial Activity}

The results of antimalarial activity are presented in Table 2 . Results reveal that all the synthesized compounds, 5a-g showed good activity ( $\mathrm{IC}_{50}$ ranges from 5.30-18.60 $\mu \mathrm{g} / \mathrm{ml}$ ) against CQ-sensitive P. falciparum (RKL-2) strain which was considerably less than that of the standard reference drug, CQ $\left(\mathrm{IC}_{50} 0.04 \mu \mathrm{g} / \mathrm{ml}\right)$. Compounds $\mathbf{5 f}$ (3-indolyl) and $\mathbf{5 g}$ (2-hydroxyphenyl) showed marginally superior activity against the CQ-sensitive RKL-2 strain than rest of the compounds in the series with $\mathrm{IC}_{50}$ values, $8.19 \mu \mathrm{g} / \mathrm{ml}$ and $5.30 \mu \mathrm{g} / \mathrm{ml}$, respectively. The activity against CQ-resistant RKL-9 strain of $P$. falciparum was also good with $\mathrm{IC}_{50}$ values, $41.77 \mu \mathrm{g} / \mathrm{ml}, 39.87 \mu \mathrm{g} / \mathrm{ml}$, and $34.59 \mu \mathrm{g} / \mathrm{ml}$ for $5 \mathrm{a}, 5 \mathrm{~b}, 5 \mathrm{e}$, respectively. From anti- malarial activity results, it is clear that Mannich base substituted tetraoxane-phenol conjugates with bulky aromatic/heteroaromatic substituent's such as indolyl (5f) and phenolic $(\mathbf{5 g})$ groups have considerably higher antimalarial potential, particularly against the sensitive strain of $\mathrm{Pf}$ than rest of the synthesized analogues. Literature reports ${ }^{18}$ suggest that 4 -aminoquinolinephenol conjugates with heteroaryl moiety substituted Mannich side chain could increase the antimalarial activity of compounds.

\section{CONCLUSION}

In this paper, a series of seven Mannich bases of tetraoxane-phenol conjugate as antimalarial compounds are newly reported. Newer tetraoxane derivatives exhibited good antimalarial activity (in vitro) against the CQ-sensitive strain of $P$. falciparum strain. The activity against CQ-sensitive strain of $P$. falciparum was better as compared to the activity seen against resistant strain. Though the activity of the compounds reported herein is comparable to the activity of standard reference drug, chloroquine, but their potency was, however, sufficiently less than that of the standard drug. Finally, it can be concluded that such unique structural features embodied in tetraoxane-phenol cojugate with Mannich base substitution may be a promising alternative of lead discovery in the development of new antimalarial agents for the effective chemotherapy of resistant malaria.

\section{ACKNOWLEDGEMENT}

Authors are thankful to SAIF, NEHU, Shillong (India) for carrying out the spectral analysis of synthesized compounds.

\section{CONFLICT OF INTEREST}

The authors declare that there is no conflict of interest.

\section{ABBREVIATION USED}

TLC: Thin layer chromatography; UV: Ultraviolet spectroscopy; FT-IR: Fourier transform infrared spectroscopy; NMR: Nuclear magnetic resonance spectroscopy; DMSO-d6: Deuterated dimethyl sulphoxide; RKL: Rourkela; RPMI: Roswell Park Memorial Institute; HEPES: (N-2-hydroxyethylpiperazine-N-2-ethane sulfonic acid).

\section{REFERENCES}

1. Available from:URL:http://www.who.int/malaria/publications/world_malaria_ report/en/. Access date: 20.01.2014. 
2. Kumawat MK, Singh UP, Singh B, Prakash A, Chetia D. Synthesis and antimalarial activity evaluation of 3-(3-(7-chloroquinolin-4-ylamino)propyl)1,3-thiazinan-4-one derivatives. Arab J Chem. 2011; in press. http://dx.doi. org/10.1016/j.arabjc.2011.07.007

3. Kumawat MK, Chetia D. Synthesis, antimalarial activity evaluation and molecular docking studies of some novel dispiro-1,2,4,5-tetraoxanes. Bangladesh J Pharmacol. 2015;10:917-23. http://dx.doi.org/10.3329/bjp. v10i4.24532

4. Roy S, Chetia D, Rudrapal M, Prakash A. Synthesis and antimalarial activity study of some new Mannich bases of 7-chloro-4 aminoquinoline. Med Chem. 2013;9(3):379-83. http://dx.doi.org/10.2174/157340641130903000; PMid:22946532.

5. Rudrapal M, Chetia D, Prakash A. Synthesis, antimalarial and antibacterial activity evaluation of some new 4-aminoquonoline derivatives. Med Chem Res. 2013;22(8):3703-11. http://dx.doi.org/10.1007/s00044-012-0371-9.

6. O'Neill PM, Amewu RK, Nixon GL, Garah FB, Mungthin M, Chadwick J, et al. Identification of a 1,2,4,5-tetraoxane antimalarial drug-development candidate (RKA182) with superior properties to the semisynthetic artemisinins. Angew Chem. 2010;49(33):5693-7 http://dx.doi.org/10.1002/ anie.201001026 ; PMid:20629058.

7. Wang X, Creek DJ, Schiaffo CE, Dong Y, Chollet J, Scheurer C, et al. Spiroadamantyl 1,2,4-trioxolane, 1,2,4-trioxane, and 1,2,4-trioxepane pairs: Relationship between peroxide bond iron(II) reactivity, heme alkylation efficiency, and antimalarial activity. Bioorg Med Chem Lett. 2009;19(16):4542-5. http://dx.doi.org/10.1016/j.bmcl.2009.07.013 ; PMid:19616946.

8. Kyle DE, Teja-Isavadharm P, Li Q, Leo, K. Pharmacokinetics and pharmacodynamics of qinghaosu derivatives: How do they impact on the choice of drug and the dosage regimens?. Med Trop. 1998;58(3 Suppl):38-44.

9. Vennerstrom JL, Dong Y, Andersen SL, Ager AL, Fu H, Miller RE. Synthesis and Antimalarial Activity of Sixteen Dispiro-1,2,4,5-tetraoxanes: AlkylSubstituted 7,8,15,16-Tetraoxadispiro[5.2.5.2] hexadecanes. J Med Chem. 2000;43(14):2753-8. http://dx.doi.org/10.1021/jm0000766 PMid:10893313.
10. Vennerstrom JL, Hong-Ning FJ, Ellis WY, Ager AL, Wood JK, et al. Dispiro1,2,4,5-tetraoxanes: A New Class of Antimalarial Peroxides. J Med Chem. 1992;35(16):3023-7. http://dx.doi.org/10.1021/jm00094a015; PMid:1501229.

11. O'Neill PM, Ellis GL, Amewu R, Sabbani RS, Stocks PA, Shone A, et al Two-Step Synthesis of Achiral Dispiro-1,2,4,5-tetraoxanes with Outstanding Antimalarial Activity, Low Toxicity, and High-Stability Profiles. J Med Chem. 2008;51(7):2170-7. http://dx.doi.org/10.1021/jm701435h ; PMid:18341274.

12. Chadwick J, Amewu RK, Marti F, Garah FB, Sharma R, Berry NG, et al. Antimalarial Mannoxanes: Hybrid Antimalarial Drugs with Outstanding Oral Activity Profiles and A Potential Dual Mechanism of Action. Chem Med Chem. 2011;6(8):1357-61. http://dx.doi.org/10.1002/cmdc.201100196; PMid:21692184.

13. Terent'ev AO, Borisov DA, Yaremenko IA. General methods for the preparation of 1,2,4,5-tetraoxanes-key structures for the development of peroxidic antimalarial agents. Chem Heterocycl Compd. 2012;48(1):55-8. http://dx.doi.org/10.1007/s10593-012-0969-3

14. Opsenica I, Opsenica D, Smith KS, Milhous WK, Solaja BA. Chemica Stability of the Peroxide Bond Enables Diversified Synthesis of Potent Tetraoxane Antimalarials. J Med Chem. 2008;51(7):2261-6. http://dx.doi. org/10.1021/jm701417a ; PMid:18330976.

15. Trager W, Jensen JB. Human malaria parasites in continuous culture. Science. 1976;193(4254):673-5. http://dx.doi.org/10.1126/science.781840; PMid:781840.

16. Sharma D, Chetia D, Rudrapal M. Design, Synthesis and Antimalarial Activity of Some New 2-Hydroxy-1,4-naphthoquinone-4-hydroxyaniline Hybrid Mannich Bases. Asian J Chem. 2016;28(4):782-8. http://dx.doi.org/10.14233/ ajchem.2016.19478

17. Silverstein RM, Webster FX. Spectrometric identification of organic compounds. $6^{\text {th }}$ ed. New York, John Wiley and Sons Ltd.; 1963. PMCid:PMC2137641.

18. O'Neil PM, Mukhtar A, Stocks PA, Randle LE, Hindley S, Ward SA, et al. Isoquine and Related Amodiaquine Analogues: A New Generation of Improved 4-aminoquinoline Antimalarials. J Med Chem. 2003;46(23):4933-45. http://dx.doi.org/10.1021/jm030796n ; PMid:14584944.

\section{SUMMARY}

- A new series of Mannich bases of tetraoxane-phenol conjugate were synthesized, characterized and evaluated in vitro for their antimalarial activity. Newer tetraoxane derivatives exhibited good antimalarial activity against both chloroquine (CQ)-sensitive and -resistant strains of $\mathrm{P}$. falciparum. The activity against $\mathrm{CQ}-$ sensitive strain was found better than the activity against resistant strain. However, in vitro antimalarial potency of these compounds was less as compared to the standard reference drug, CQ. From results, finally it can be concluded that conjugated tetraoxane-phenol structural scaffold with Mannich base substitutions like bulky aromatic/heteroaromatic groups have antimalarial potential, which could therefore be a promising alternative sources of novel antimalarial leads in the development of potent antimalarial drugs for the treatment of resistant malaria.

\section{About Authors}

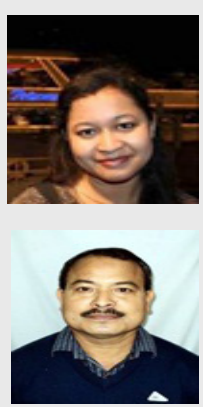

Ms. Jinky Gogoi: She Is working as Drug Safety Associate at Quintiles Research, Bengaluru, India. Ms. Gogoi did M. Pharm. with specialization in Pharmaceutical Chemistry from Dept. of Pharmaceutical Sciences, Dibrugarh University, Dibrugarh, Assam (India).

Dr. Dipak Chetia: He is Professor and Head at the Dept. of Pharmaceutical Sciences, Dibrugarh University, Dibrugarh, Assam (India). Dr. Chetia has been engaged in teaching and research since 1990. His research interests include antimalarial drug development from natural and synthetic sources. He has published a good number of papers in various journals and books. 


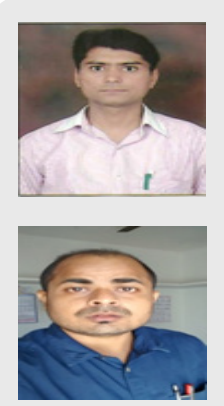

Dr. Mukesh Kumar Kumawat: He is presently working as Assistant Professor at Anand College of Pharmacy, Agra, Uttar Pradesh (India). Dr. Kumawat obtained his Ph. D. degree in Pharmacy from Dibrugarh University in 2016. His research interest is development of synthetic bio-molecules for application as potent antimalarial agents. He has a number of research publications to his credit.

Mr. Mithun Rudrapal: $\mathrm{He}$ is currently pursuing his $\mathrm{Ph}$. D. degree in the development of new antimalarial drugs from synthetic sources at the Dept. of Pharmaceutical Sciences, Dibrugarh University, Dibrugarh, Assam (India). Mr. Rudrapal completed M. Pharm. with specialization in Pharm. Chemistry from the same University. He has published a number of papers in various journals. 